This is the post-print version of an article published in Ecological Indicators. Please cite this article as follows:

Lambrechts, W. and Van Liedekerke, L. (2014). Using ecological footprint analysis in higher education: Campus operations, policy development and educational purposes. Ecological Indicators, Vol. 45, pp. 402-406.

To link to this article: http://www.sciencedirect.com/science/article/pii/S1470160X14001940

\title{
Using ecological footprint analysis in higher education: campus operations, policy development and educational purposes
}

Wim Lambrechts*12, Luc Van Liedekerke ${ }^{23}$

${ }^{1}$ Leuven University College (KHLeuven), Department of Business Studies

${ }^{2}$ University of Antwerp (UA), Department of Philosophy

${ }^{3}$ University of Leuven (KU Leuven), Centre for Economics and Ethics

* Wim Lambrechts is holder of a Special PhD Fellowship of the Research Foundation - Flanders (FWO). e-mail address: wim@lambrechts.org, website: www.sustainablehighereducation.com

\begin{abstract}
Ecological footprint analysis has been used worldwide in a variety of organisations (enterprise, public authorities, non-governmental organisations, (higher) educational institutions) and at different levels (personal level, (parts of) organisations, cities, regions, countries). Universities also calculated their ecological footprints, for various reasons: e.g. to answer the societal appeal to integrate sustainability into their core business, to perform a sustainability assessment of their operations, to use as an educational tool with students, to use for policy development. In general, performing an
\end{abstract}


ecological footprint analysis is a way for higher education to 'practice what they preach', to monitor sustainability performance and raise awareness among the university's community. This article focuses on the calculation of the ecological footprint and discusses the possibilities to use this tool for campus operations, educational purposes and policy development.

\section{Keywords}

ecological footprint analysis; sustainable higher education; education for sustainable development; higher education policy; sustainability assessment

\section{Introduction}

In the past years, higher education institutions (HEIs) worldwide have been encouraged to strengthen their role in achieving sustainable societies. As key educational actors in society, they are supposed to prepare students to the challenges connected to sustainable development (SD), which society is facing today and in the future. A multitude of charters and declarations pointed towards the role HEls can play within their policy, education, research and operations (Lozano et al., 2013). A lot of attention is given towards educational initiatives, competences for SD, and reorienting curriculum towards SD (e.g. Lambrechts et al., 2013). Under the credo 'practice what you preach', the integration of SD in higher education can only be effective and credible if the $\mathrm{HEl}$ is playing an exemplary role, i.e. also incorporating SD principles within its own operations and management (Waas et al., 2012). Therefore, universities worldwide take considerable steps to integrate SD within their operations through practical initiatives, e.g. developing environmental management systems, sustainability assessment and reporting (Lozano et al., 2013). Performing an ecological footprint analysis (EFA) also fits within HEls' strategy to 'practice what they preach', resulting in reports on the ecological footprint (EF) of numerous HEls worldwide. These reports show several reasons why universities use EFA: monitoring ecological performance, determining where the greatest impact is occurring, raising awareness among staff and students by involving them in the process of calculation (Gottlieb et al., 2012).

One of the HEls to calculate its EF is Leuven University College (KHLeuven), a Belgian HEl located in the Province of Flemish Brabant, $30 \mathrm{~km}$ from the city of Brussels. KHLeuven provides professional bachelor programs in four departments: Business Studies, Teacher Training, Social Work, Health Care and Technology. In 2010, KHLeuven counted 6.914 students and 704 staff members. During the past ten years, numerous educational, operational and management initiatives were started to integrate SD within the organisation, calculating the EF was one of these initiatives (for an overview of SD initiatives in KHLeuven, please refer to Lambrechts et al., 2008, 2009, Lambrechts and Ceulemans, 2013, Verhulst and Lambrechts, 2013).

This paper focuses on the calculation of the $\mathrm{EF}$, and the possibilities to use it for campus operations, policy development and educational purposes. The paper starts with the method used for the EFA in section 2. Section 3 elaborates on critiques on the use of EFA. Section 4 presents the results of the EFA at KHLeuven, including a calculation of the carbon footprint, and an overview of EFA results of other HEls. Section 5 highlights the discussion on the use of EFA within campus operations, policy 
development and educational purposes. Section 6 provides general conclusions on the use of EFA in higher education.

\section{Method for calculation of the ecological footprint}

The method used to calculate the EF of KHLeuven was the componential method, as developed by the Global Footprint Network, based on Wackernagel and Rees (1996). In this method, the land used to provide in our daily production and consumption needs is estimated. Six different types of land footprints are defined: cropland footprint, grazing land footprint, forest footprint, fishing grounds footprint, carbon footprint, built-up land footprint. Each of these categories has its own biocapacity, quantified and expressed in global hectares (gha), which is an average of the productivity of the earth's land areas in one year. In order to estimate the EF, several components are defined, related to consumption of materials and emission of waste (Kitzes et al., 2008).

In a first step of the analysis, the components necessary to calculate the EF of KHLeuven were selected: direct energy use (including use of natural gas, oil and electricity), water (tap water and rainwater), mobility (including commuting, travel by air and other service trips), procurement (of paper, office equipment, courses for students), waste (recycled and non-recycled), food (consumption in campus restaurants) and infrastructure (construction of buildings, furniture and ICT equipment). In a second step, the reference units within this study were defined: the EFA is calculated using data of the reference year 2010, at the level of the four departments (located at 5 campuses) and one administrative department, for each of the seven components, and per capita (staff and students, $\mathrm{n}=7.618$ ). In addition, both the $\mathrm{EF}$ and the carbon footprint (CF) have been calculated. In order to define strengths and weaknesses of the use of EFA within the context of higher education, a workshop was organised in November 2012, to discuss the results and the use of EFA for campus operations, policy development and educational purposes with internal and external stakeholders.

\section{Critical reflections on the use of the ecological footprint}

Since presenting the method of EFA by Wackernagel and Rees (1996), a number of critiques on the concept and use of EFA were published. An exhaustive overview of critiques would stretch beyond the scope of this article, however some critical reflections are highlighted as they provide valuable input for the use of EFA in higher education. Conceptual critiques point out to the desirability to integrate complex issues into one indicator. The EF is a method to translate the complexity of ecological pressure into an understandable framework. However, aiming towards one integrated indicator comprises the risk of oversimplification, under- or overestimation of unknown components, on their turn resulting in the inability to compare results (McManus and Haughton, 2006, Nunes et al., 2013).

Another critique points out that boundaries set in an EFA are arbitrary, which means there's a risk they are meaningless within the context of cross-country comparing, as pointed out by Fiala (2008) and McManus and Haughton (2006). Furthermore, some components are not taken into account, e.g. depletion of raw materials, which could lead to an underestimation of the ecological pressure. 
Regarding the waste component, only energy and land used for its collection, transport and processing is taken into account, and not the long term effect, nor the effects of nuclear and chemical waste. The water component accounts for the extraction and purification, and the built area, pipelines and transport related to this process, the water consumption itself is not taken into account. Again, omitting certain components can be problematic for comparability purposes of EFA (Fiala, 2008, McManus and Haughton, 2006, Nunes et al., 2013).

Other critiques point to the lack of attention or differentiation, mainly concerning differences in productive and absorptive capacities, as well as carrying capacities of areas; possible benefits of technological advances; the assumption that land can only be used for a single (or ecological) function; and the role and possible changes in social welfare (McManus and Haughton, 2006). Overall, using an EFA should be prepared and interpreted carefully, taking into account critical reflections regarding components, estimations, assumptions and comparisons.

\section{Results}

The EF of KHLeuven is presented in table 1, with an overview per component, and the EF expressed in global hectare (gha). The total EF of KHLeuven in reference year 2010 is $2.663,70$ gha. This is 1.200 times higher than the biocapacity of its physical area, thus largely exceeding the ability of its physical area to produce materials for, and absorb emissions of, the organisation. The EF per capita is 0.35 gha, thus working or studying at KHLeuven raises an individuals' personal EF by 0.35 gha.

Mobility, and mainly commuting accounts for almost half of the EF (44,22\%). Procurement of paper and handbooks for students accounts for up to $24 \%$ of the $E F$, while the direct energy use accounts for $17,83 \%$. The fourth component with considerable impact is infrastructure, which accounts for up to $10 \%$. Waste and water use do not have a big impact on the EF of KHLeuven. Figure 1 shows the percentage distribution of each component of the EF. Also, the analysis pointed out that the EF for different components could differ strongly between the departments/campuses of KHLeuven. A differentiated and locally oriented approach of the EF is important, as components with a high impact in one campus could have a low impact in another campus. These results are in line with other findings reported in the literature (for EF see: Townsend and Barrett, 2013, for CF see: Larsen et al., 2013).

Table 1. The ecological footprint of KHLeuven (reference year: 2010)

\begin{tabular}{lrrrr}
\hline Component & $\begin{array}{r}\text { Ecological } \\
\text { footprint }\end{array}$ & $\begin{array}{r}\text { \% of total } \\
\text { EF }\end{array}$ & $\begin{array}{r}\text { Carbon } \\
\text { footprint }\end{array}$ & $\begin{array}{r}\text { \% of total } \\
\text { CB }\end{array}$ \\
\hline Direct energy use & $\begin{array}{r}475,00 \text { gha } \\
\text { Heating }\end{array}$ & $17,83 \%$ & $1.839 \mathrm{t}$ & $26,00 \%$ \\
$\quad \begin{array}{l}255,00 \text { gha } \\
220,00 \text { gha }\end{array}$ & & & \\
$\quad$ Electricity & 0,30 gha & $0,01 \%$ & $1 \mathrm{t}$ & $0,00 \%$ \\
Water use & 0,30 gha & & & \\
$\quad$ Water use from tap & 1,40 gha & $0,05 \%$ & $5 \mathrm{t}$ & $0,10 \%$ \\
Waste & 0,10 gha & & & \\
$\quad$ Recycled & 1,30 gha & & & \\
$\quad$ Non-recycled & & & & \\
\hline
\end{tabular}




\begin{tabular}{|c|c|c|c|c|}
\hline Mobility & $1.178,00$ gha & $44,22 \%$ & $3.362 t$ & $47,40 \%$ \\
\hline Commuting staff & 141,00 gha & & & \\
\hline Commuting students & 975,00 gha & & & \\
\hline $\begin{array}{l}\text { Other service trips (including air } \\
\text { travel) }\end{array}$ & 62,00 gha & & & \\
\hline Procurement & 631,00 gha & $23,69 \%$ & $906 \mathrm{t}$ & $12,80 \%$ \\
\hline Paper & 214,00 gha & & & \\
\hline Office equipment & 2,00 gha & & & \\
\hline Other equipment & 93,00 gha & & & \\
\hline Books and courses for students & 322,00 gha & & & \\
\hline Infrastructure & 251,00 gha & $9,42 \%$ & $972 \mathrm{t}$ & $13,70 \%$ \\
\hline Buildings & 121,00 gha & & & \\
\hline Furniture & 18,00 gha & & & \\
\hline ICT equipment & 111,00 gha & & & \\
\hline Food & 127,00 gha & $4,77 \%$ & na & na \\
\hline Meals on campus & 92,00 gha & & & \\
\hline Coffee and cold drinks on campus & 35,00 gha & & & \\
\hline Total for all components & $2.663,70$ gha & $100,00 \%$ & $7.085 t$ & $100 \%$ \\
\hline EF per ha & $1.286,81 \mathrm{gha}$ & & & \\
\hline EF/CF per person (staff + students) & 0,35 gha & & $0,93 \mathrm{t}$ & \\
\hline
\end{tabular}

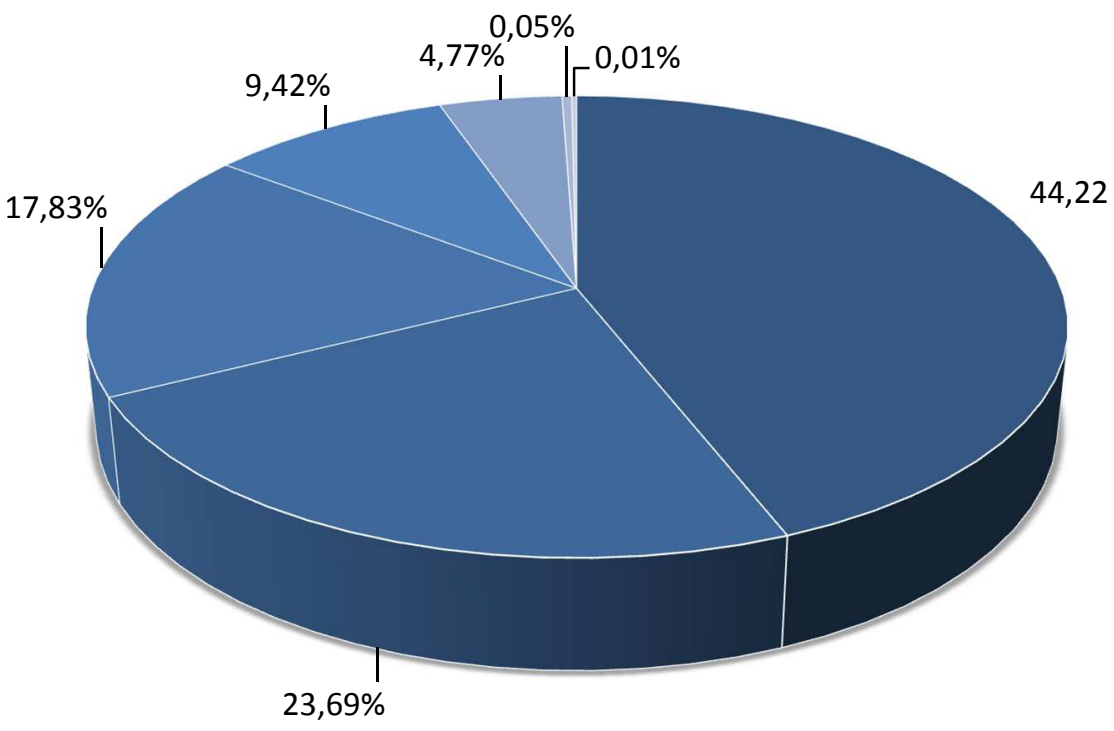

- Mobility

- Procurement

- Direct energy use

- Infrastructure

Food

Waste

Water use

Figure 1. Percentage of each component in KHLeuven's EF (reference year: 2010) 
The results of the analysis regarding the CF are also included in table 1. The total CF of KHLeuven is 7.085 ton. This means for all calculated components, 7.085 tons $\mathrm{CO} 2$ emissions are released, or an average of 0,93 ton per capita. The CF includes three types of emissions. ISO scope 1 comprises direct emissions of the organisation (e.g. due to heating of buildings), ISO scope 2 comprises the indirect emissions due to the use of electricity, ISO scope 3 comprises all other indirect emissions (e.g. commuting, procurement of goods). Table 2 shows the CF calculation of KHLeuven, taking into account the three scopes. The percentage distribution of each component in the CF is comparable with the EF, with the exception of procurement, which accounts for only half the percentage in the CF. This difference occurs due to the fact that the use of woodlands for paper production is taken into account in the EF, but not in the CF.

Table 2. Carbon Footprint of KHLeuven (reference year: 2010)

\begin{tabular}{|l|r|r|r|r|r|}
\hline Component & \multicolumn{1}{l|l|l|l|}{$\begin{array}{l}\text { ISO Scope 1 } \\
\text { (t CO2) }\end{array}$} & $\begin{array}{l}\text { ISO Scope 2 } \\
\text { (t CO2) }\end{array}$ & $\begin{array}{l}\text { ISO Scope 3 } \\
\text { (t CO2) }\end{array}$ & $\begin{array}{l}\text { Total } \\
\text { (t CO2) }\end{array}$ & \% of total CB \\
\hline $\begin{array}{l}\text { Direct energy } \\
\text { use }\end{array}$ & 888 & 815 & 137 & 1.839 & $26,00 \%$ \\
\hline Water use & - & - & 1 & 1 & $0,00 \%$ \\
\hline Waste & - & - & 5 & 5 & $0,10 \%$ \\
\hline Mobility & 72 & - & 3.289 & 3.361 & $47,40 \%$ \\
\hline Procurement & - & - & 906 & 906 & $12,80 \%$ \\
\hline Infrastructure & - & - & 972 & 972 & $13,70 \%$ \\
\hline Total & 960 & 815 & 5.310 & 7.085 & $100,00 \%$ \\
\hline Per capita & 0,12 & 0,11 & 0,70 & 0,93 & \\
\hline
\end{tabular}

Table 3. Overview of EFA results of different universities

\begin{tabular}{|c|c|c|c|c|c|c|c|}
\hline \multicolumn{2}{|c|}{ HEI } & \multirow{2}{*}{$\begin{array}{l}\text { Reference } \\
\text { year } \\
2010\end{array}$} & \multirow{2}{*}{$\begin{array}{l}\begin{array}{l}\text { Total EF } \\
\text { (gha) } \\
2.663\end{array} \\
\end{array}$} & \multirow{2}{*}{$\begin{array}{l}\text { EF per } \\
\text { capita } \\
\text { (gha) } \\
0.35\end{array}$} & \multicolumn{2}{|c|}{$\begin{array}{l}\text { Most important } \\
\text { component (\% of } \\
\text { EF) }\end{array}$} & \multirow{2}{*}{$\begin{array}{l}\text { Source } \\
\text { This study }\end{array}$} \\
\hline 1 & KHLeuven & & & & Mobility & $44,22 \%$ & \\
\hline 2 & $\begin{array}{l}\text { University of Illinois at } \\
\text { Chicago }\end{array}$ & 2008 & 97.601 & 2.66 & Energy & $72,66 \%$ & $\begin{array}{l}\text { Klein-Banai } \\
\text { and Theis } \\
(2011)\end{array}$ \\
\hline 3 & University of Redlands & 1997 & 5.700 & 0.90 & Energy & $49,50 \%$ & $\begin{array}{l}\text { Venetoulis } \\
(2001)\end{array}$ \\
\hline 4 & $\begin{array}{l}\text { University of Newcastle, } \\
\text { Australia }\end{array}$ & 1999 & 3.592 & 0.19 & Energy & $47,00 \%$ & Flint (2001) \\
\hline 5 & Holme Lacy College (UK) & 2001 & 296 & 0.57 & $\begin{array}{l}\text { Materials and } \\
\text { waste }\end{array}$ & $32,00 \%$ & $\begin{array}{l}\text { Dawe et al. } \\
(2004)\end{array}$ \\
\hline 6 & $\begin{array}{l}\text { Northeastern University } \\
\text { (China) }\end{array}$ & 2003 & 24.787 & 1.06 & Energy & $67,97 \%$ & $\begin{array}{l}\text { Li et al. } \\
(2008)\end{array}$ \\
\hline 7 & $\begin{array}{l}\text { University of Toronto at } \\
\text { Mississauga }\end{array}$ & 2005 & 8.744 & 1.07 & Energy & $69,40 \%$ & $\begin{array}{l}\text { Conway et al. } \\
(2008)\end{array}$ \\
\hline 8 & Colorado College & NA & 5.603 & 2.24 & Energy & $87,00 \%$ & $\begin{array}{l}\text { Wright } \\
(2002)\end{array}$ \\
\hline 9 & $\begin{array}{l}\text { Kwantlen University } \\
\text { College }\end{array}$ & 2005 & 3.039 & 0.33 & Transportation & $53,00 \%$ & $\begin{array}{l}\text { Burgess and } \\
\text { Lai }(2006)\end{array}$ \\
\hline 10 & Ohio State University, & 2007 & 650.666 & 8.66 & Transportation & $72,24 \%$ & Janis (2007) \\
\hline
\end{tabular}




\begin{tabular}{|r|l|l|r|r|l|l|l|}
\hline 11 & Columbus & & & & & & \\
\hline 12 & Willamette University & $2007 / 08$ & 7.804 & 2.30 & Mobility & $43,00 \%$ & $\begin{array}{l}\text { Torregrosa- } \\
\text { López et al. } \\
(2011)\end{array}$ \\
\hline 13 & $\begin{array}{l}\text { University of East Anglia } \\
\text { University León }\end{array}$ & NA & 23.455 & 7.30 & Waste & $72.30 \%$ & $\begin{array}{l}\text { Wright et al. } \\
(2009)\end{array}$ \\
\hline 14 & $\begin{array}{l}\text { University of Valencia } \\
\text { (tree campus) }\end{array}$ & 2009 & 6.300 & 0.45 & Energy & $62,00 \%$ & $\begin{array}{l}\text { Hernández et } \\
\text { al. (2009) }\end{array}$ \\
\hline 15 & $\begin{array}{l}\text { University of Santiago } \\
\text { Compostela }\end{array}$ & 2007 & 39.853 & 0.81 & Built land & $55,00 \%$ & $\begin{array}{l}\text { López et al. } \\
(2010)\end{array}$ \\
\hline 16 & $\begin{array}{l}\text { University Coruña } \\
17\end{array}$ & NA & 5.159 & 0.16 & Energy & $63,00 \%$ & $\begin{array}{l}\text { Álvarez } \\
(2008)\end{array}$ \\
\hline
\end{tabular}

In order to be able to interpret the results of KHLeuven's EFA, table 3 shows an overview of EFA results reported by HEls around the world. A selection of HEls was made based on published EFA's in international journals and conference proceedings. Table 3 shows both the total and the per capita footprint, the component with the highest impact (percentage), and the source where the EFA of each university was reported.

For the majority of HEls ( $n=9$ ), energy has the highest impact, with a range between 47 and $90 \%$ of the total EF. Mobility and transportation has the highest impact in $4 \mathrm{HEls}$, with a range between 43 and $73 \%$. The total EF of each HEl ranges between 296 gha and 650.666 gha, the per capita EF ranges between 0.15 and 8.66 gha, this clearly refers to differences in EF approach and difficulties to use EFA for comparative purposes.

\section{Discussion: use of the ecological footprint in operations, policy and education}

The initial purpose of performing the EFA at KHLeuven was (1) to have a clear view on the institution's ecological impact (operations), (2) to serve as a base for further policy planning in the future, (3) to raise awareness among staff and students (through education). The possibilities to use EFA in operations, policy and education were discussed with internal stakeholders of KHLeuven (through face-to-face interviews with teachers, administrative staff, and management), and external stakeholders, through a workshop attended by other HEls representatives, local policy representatives and NGO's (organised in November 2012).

Regarding operations, university staff members had the impression that a clear view on the input and output of the institution was missing, and expressed the wish to have clear quantitative data about different aspects of operations. In expressing this purpose, the EFA also served as a baseline for further policy development, mainly regarding the institutions' operations. In order to guide further initiatives within campus operations, a set of scenarios was developed in order to lower the EF. The scenarios pointed out that priority should be given towards electricity use, with a potential of almost $10 \%$ reduction, reducing paper use and changing to recycled paper, with a potential of $6 \%$ reduction. By far the hardest component to tackle is mobility, as the majority of staff and students use their car 
for commuting. Scenarios and initiatives for this component could not be identified within the scope of the project, but will be developed in the future.

Regarding policy development and management, the EFA has led to defining qualitative and quantitative indicators for the quality monitoring system. Within operations, a qualitative indicator would be 'preparing an internal environmental care system', measured within the sustainability assessment based on the Auditing Instrument for Sustainability in Higher Education (AISHE), which KHLeuven used on a regular base (Lambrechts and Ceulemans, 2013). Quantitative indicators to integrate within operations were defined as: amount of purchased paper $(\mathrm{kg}$, recycled/non-recycled, measured by financial department using invoices); amount of water used $\left(\mathrm{m}^{3}\right.$, measured by financial department using invoices); amount of waste ( $\mathrm{kg}$, different categories); amount of energy use (gas, electricity), mobility of staff (commuting by car, bike, service trips by plane), mobility of students. All of these indicators could be measured by the financial department, using invoices, with the exception of students' mobility, as this indicator would require a periodic survey. Regarding education, qualitative indicators would be linked with the use of AISHE, while quantitative indicators were defined as: number of courses with clear reference to SD, corporate social responsibility, ecological footprint, etc. (measured in the ECTS fiches); number of students involved in research and outreach projects regarding SD (measured within project registration system). However, the possibilities and utility of these quantitative indicators were under discussion, as stakeholders tended to have a preference towards a qualitative approach within education and research.

Regarding the use of EFA for educational purposes, stakeholders discussed the way EFA could be used with students. Different possibilities were expressed: students calculate their own personal footprint; involve students in the calculation of the university's EF; use EFA results in courses to further develop SD awareness initiatives by students. It was pointed out that the EF should not be seen as an ultimate goal or end-result of a university's efforts to incorporate ecological indicators. It rather serves as a basis to raise awareness, and to guide the integration of sustainability. When using EFA for educational purposes, one should use it as a starting point, and go beyond the mere results of numbers and global hectares. This means taking into account and further elaborating on the notion of boundaries, historical perspectives, inequality between North and South, etc. In doing this, the EFA can contribute to the acquisition of key competences for SD, i.e. systems thinking, future thinking, critical thinking about values and responsibility, personal action taking (Lambrechts et al., 2013).

\section{Conclusions}

This paper discussed the use of EFA within higher education, with a focus on campus operations, policy development and educational purposes. EFA may seem as an appropriate way to integrate SD, and more specifically environmental performance, in the university's own operations, policy planning and education, as was the case for KHLeuven. However, some reflections should be taken into account when launching such an initiative.

Several authors point to the fact that the methods used are not suitable to compare results between different EFA's (Fiala, 2008), leading to initiatives to provide a framework for inter-comparison of EFA's (Nunes et al., 2013). These reflections were also made within KHLeuven, mainly out of concern 
the methodology used within the EFA would guarantee a sound base for future actions in campus operations. However, one should use and interpret EFA careful. The example of mobility is emblematic: this is by far a very difficult issue and it would be too easy to just exclude it from a university's EFA for the sake of comparability. Within KHLeuven, the EFA was used to take further steps to integrate SD within its own operations, by developing scenarios to reduce the EF.

Regarding policy development, EFA could be used to define indicators to integrate in the quality monitoring system. Participants in the EFA project expressed their wish for quantitative indicators, which were defined for operations. This points out to the current tendency towards quantitative indicators and management control systems within higher education. However useful within the context of monitoring campus operations, this approach should be introduced carefully within education and research. Participants expressed a clear preference for qualitative indicators, in order to avoid too much attempts to quantify courses and omitting qualitative content of education and research within the quality system.

Regarding the use of EFA for educational purposes, participants pointed out to the potential of the concept at different levels: personal level, course level, university level. Involving students in the university's efforts to calculate its EF is seen as a valuable approach, and is in line with the goals and methods of education for sustainable development (ESD). However useful for educational purposes and raising awareness, attention should be given towards enabling university teachers to use EF concepts within education. In other words, educate-the-educator, as pointed out by Lozano et al. (2013) remains a key factor, also for the use of EFA within education.

Above all, when using the concept of EF in higher education, one should not get lost in the numbers, and the EF should be used and interpreted for what it's worth, i.e. (1) a static snapshot giving an indication of the university's impact on the environment at a given moment; (2) a useful framework to further work on key components of ecological impact within campus operations; and (3) an awareness-raising tool to engage staff and students to take initiatives towards integrating sustainability within higher education.

\section{Acknowledgements}

This article is based on the project "Ecological Footprint in Higher Education: Calculation and Further Steps towards Organisational Development" (2011-2012), supported by the Province of Flemish Brabant. The author would like to thank colleagues of the Province of Flemish Brabant, Ecolife and KHLeuven for their valuable input and support for this project.

\section{References}

Álvarez, N., 2008. Metodologia para el Calculo de la huella ecologica en universidades. In: Congresso Nacional del Medio ambiente, Cumbre del Desarrollo Sostenible, Congresso Nacional del Medio ambiente, Cumbre del Desarrollo Sostenible, Madrid. 
Burgess, B., Lai, J., 2006. Ecological footprint analysis and review: Kwantlen University College. Kwantlen University College, Canada.

Conway, T.M., Dalton, C., Loo, J., Benakoun, L., 2008. Developing ecological footprint scenarios on university campuses: a case study of the University of Toronto at Mississauga. Int. J. Sustain. High. Educ., 9, 4-20.

Dawe, G.F.M., Vetter, A., Martin, S., 2004. An overview of ecological footprinting and other tools and their application to the development of sustainability process: audit and methodology at Holme Lacy College, UK. Int. J. Sustain. High. Educ., 5, 340-371.

Fiala, N., 2008. Measuring sustainability: why the ecological footprint is bad economics and bad environmental science. Ecol. Econ., 67, 519-525.

Flint, K., 2001. Institutional ecological footprint analysis - a case study of the University of Newcastle, Australia. Int. J. Sustain. High. Educ., 2, 48-62.

Gottlieb, D., Kissinger, M., Vigoda-Gadot, E. and Haim, A., 2012. Analyzing the ecological footprint at the institutional scale - The case of an Israeli high-school. Ecol. Indic., 18, 91-97.

Janis, J.A., 2007. Quantifying the Ecological Footprint of the Ohio State University. Ohio State University, Columbus.

Kitzes, J., A. Galli, S.M. Rizk, A. Reed and Wackernagel, M., 2008. Guidebook to the National Footprint Accounts: 2008 Edition. Global Footprint Network, Oakland.

Klein-Banai, C., Theis, T.L., 2011. An urban university's ecological footprint and the effect of climate change. Ecol. Indic., 11, 857-860.

Lambrechts, W. and Ceulemans, K., 2013. Sustainability Assessment in Higher Education. Evaluating the Use of the Auditing Instrument for Sustainability in Higher Education (AISHE) in Belgium. In: Caeiro, S., Leal Filho, W., Jabbour, C., Azeiteiro, U. (Eds.). Sustainability Assessment Tools in Higher Education Institutions. Mapping Trends and Good Practice Around the World. Springer, 157-174.

Lambrechts, W., Mulà, I., Ceulemans, K., Molderez, I. and Gaeremynck, V., 2013. The integration of competences for sustainable development in higher education: an analysis of bachelor programs in management, J. Clean. Prod., 48, 65-73.

Lambrechts, W., Vanhoren, I. en Van den Haute, H., 2009. Duurzaam hoger onderwijs. Appel voor verantwoord onderrichten, onderzoeken en ondernemen [Sustainable higher education. Appeal for responsible education, research and operations]. LannooCampus, Leuven.

Lambrechts, W., Van den Haute, H. and Vanhoren, I., 2008. Making progress towards sustainable higher education: design of an implementation model with guiding principles. Businet Annual Conference (Palma de Majorca, 12-15 november 2008).

Larsen, H.N., Petterson, J., Solli, C. and Hertwich, E.G., 2013. Investigating the Carbon Footprint of a University - The case of NTNU. J. Clean. Prod., 48, 39-48. 
Li, G.J., Wang, Q., Gu, X.W., Liu, J.X., Ding, Y., Liang, G.Y., 2008. Application of the componential method for ecological footprint calculation of a Chinese university campus. Ecol. Indic., 8, 75-78.

López, J., Ferreira, V., Lagardela, D., Barranco, C., 2010. Un indicador ambiental para medir la sostenibilidad en las Universidades, la Huella Ecologica. In: Caso de estudio de la Universidad Politecnica de Valencia, Congresso Nacional del Medio Ambiente, 22-26 November, Madrid.

Lozano, R., Lukman, R., Lozano, F.J., Huisingh, D. and Lambrechts, W., 2013. Declarations for sustainability in higher education: becoming better leaders, through addressing the university system. J. Clean. Prod., 48, 10-19.

McManus, P. and Haughton, G., 2006. Planning with Ecological Footprints: a sympathetic critique of theory and practice. Environ. Urban., 18 (1), 113-127.

Nunes, L.M., Catarino, A., Ribau Teixeira, M. and Cuesta E.M., 2013. Framework for the intercomparison of ecological footprint of universities. Ecol. Indic., 32, 276-284.

Torregrosa-López, J.I., Navarro, C.G.B., Lo lacono-Ferreira, V.G., 2011. Experiences in the use of ecological footprint as a sustainability indicator. Cuad. Biodivers. 37, 9-18.

Townsend, J., Barrett, J., 2013 (in press). Exploring the applications of carbon footprinting towards sustainability at a UK university: reporting and decision making, J. Clean. Prod. (in press), doi: 10.1016/j.jclepro.2013.11.004.

Venetoulis, J., 2001. Assessing the ecological impact of a university: the ecological footprint for the University of Redlands. Int. J. Sustain. High. Educ., 2, 180-197.

Verhulst, E. and Lambrechts, W., 2013. Fostering the incorporation of SD into the university system. Lessons learned from a change management perspective. ERSCP-EMSU 2013, Istanbul, Turkey.

Waas, T., Hugé, J., Ceulemans, K., Lambrechts, W., Vandenabeele, J., Lozano, R. and Wright, T., 2012. Sustainable Higher Education. Understanding and Moving Forward. Flemish Government Environment, Nature and Energy Department, Brussels.

Wackernagel, M. and Rees, W., 1996. Our Ecological Footprint: Reducing Human Impact on the Earth. New Society Publishers, Canada.

Wright, E.P., 2002. The Ecological Footprint of the Colorado College: an Examination of Sustainability. Colorado College, Colorado, USA.

Wright, E., Gill, B., Wallin, P., Hutchison, K., Prebble, M., 2009. The Ecological Footprint of UEA: Calculation, Analysis and Strategies, ENV 3A20: Global Environmental Change. University of East Anglia, East Anglia, UK. 